\title{
KONTESTASI ELITE POLITIK DALAM PERUBAHAN APBD TAHUN 2017 KABUPATEN SIDOARJO
}

\author{
Istighfarin Nur Fitriah $^{1}$, Wisnu Pramutanto ${ }^{2}$ \\ ${ }^{1}$ Departemen Politik, Fakultas Ilmu Sosial dan Ilmu Politik, Universitas Airlangga \\ Istighfarin.nur.fitriah-2013@fisip.unair.ac.id \\ ${ }^{2}$ Departemen Politik, Fakultas Ilmu Sosial dan Ilmu Politik, Universitas Airlangga \\ wisnu.pramutanto@fisip.unair.ac.id
}

\begin{abstract}
Abstrak: Penelitian ini memfokuskan kajian bagaimana kontestasi elite politik dalam proses perubahan APBD tahun 2017 di DPRD Kabupaten Sidoarjo. Tujuan penelitian ini adalah untuk mengetahui kontestasi elite politik dalam proses perubahan APBD tahun 2017, mengetahui apa yang diperjuangkan, dan untuk mengetahui siapa yang diuntungkan dalam kontestasi elite politik dalam perubahan APBD tahun 2017. Penelitian ini menggunakan metode penelitian kualitatif. Proses pengumpulan data primer melalui indepth interview dilakukan dengan menempatkan informan pada kapasitas sebagai DPRD Sidoarjo. Teknik pemilihan informan adalah purposive sampling. Hasil penelitian menunjukkan kontestasi elite politik dalam proses perubahan APBD tahun 2017 dijelaskan dengan adanya kontestasi pihak elite politik seperti kelompok kepentingan mengembangkan potensinya dan meningkatkan kapasitasnya secara bersama-sama, sehingga memiliki pemahaman yang sama baiknya dalam menyikapi setiap isu perubahan APBD tahun 2017 dan implementasinya. Pihak yang berkontestasi adalah pihak eksekutif dari tim anggaran Kabupaten Sidoarjo dan pihak wakil rayat DPRD Kabupaten Sidoarjo dalam arena perubahan APBD Kabupaten Sidoarjo tahun 2017 tentang anggaran Dinas Pendidikan Kabupaten Sidoarjo. Hal yang diperjuangkan dalam kontestasi politik terhadap perubahan APBD tahun 2017 dijelaskan kepentingan antara badan legislatif dan eksekutif terutama dinas pendidikan yang membela kepentingan guru dan kebutuhan pendidikan.
\end{abstract}

Kata kunci: Kontestasi, Elite Politik, Sidoarjo.

\section{PENDAHULUAN}

APBD yang merupakan pondasi pemerintah daerah dalam membuat kebijakan-kebijakan dan pedoman dalam jalannya pemerintahan daerah, maka penetapan dan pengesahan APBD yang tepat waktu merupakan hal penting. Hal ini tidak terlepas membantu terutama untuk mempercepat proses pembangunan di daerah melalui pelaksanaan program-program pemerintah dalam tahun anggaran. Selain itu, perubahan APBD yang tepat waktu juga akan menghindari suhu politik yang memanas di daerah, sehingga akan mengundang investor untuk berinvestasi di daerah tersebut karena iklim investasi yang kondusif.

Ada perbedaan yang mendasar dalam perubahan APBD antara sebelum dan sesudah otonomi daerah. Pada sebelum otonomi daerah, perubahan APBD cenderung berstruktur sentralisasi yang didasarkan pada keputusan pihak-pihak tertentu (kepala daerah atau sekretaris daerah). Masing-masing Satuan Kerja Perangkat Daerah (SKPD) kurang berperan dalam proses penyusunan anggaran. Anggaran sangat diperlukan dalam pengelolaan sumber daya untuk mencapai kinerja yang diharapkan. Sedangkan setelah otonomi, perubahan APBD bersifat desentralisasi. Desentralisasi disini ialah bahwa dalam perubahan APBD harus berdasarkan partisipasi, kejelasan sasaran anggaran, dan struktur yang terdesentralisasi. Oleh karena itu, dalam rangka menyiapkan rancangan APBD, pemerintah daerah bersama DPRD berpartisipasi menyusun arah dan kebijakan umum APBD yang memuat petunjuk dan ketentuan-ketentuan umum yang disepakati dalam batas waktu yang ditentukan sebagai pedoman dalam 
penyusunan APBD. Arah dan kebijakan umum APBD memuat komponen-komponen pelayanan dan tingkat pencapaian yang diharapkan pada setiap lini kewenangan pemerintah yang akan dilaksanakan dalam satu tahun anggaran secara obyektif.

Perancangan APBD oleh elite politik, termasuk dewan, dijumpai banyak kendala dalam proses legislasi. Saat ini anggota dewan lalai dalam proses legislasi dan menyelesaikan pembahasan RUU dikarenakan tidak adanya kepastian prioritas itu sendiri. Hal ini diakibatkan tidak adanya panduan yang jelas mengenai mekanisme yang resmi dalam menyusun ataupun melakukan prioritas pembuatan legislasi. Kondisi legislasi yang ada menyebabkan pembentukan sistem yang jelas menjadi kebutuhan yang mendesak, ditunda, dibahas, kemudian dibiarkan dalam waktu yang tidak jelas menjadi barang yang langka dalam pembicaraan persoalan legislasi di Indonesia. Apabila ada sistem yang jelas tentunya akan membawa kejelasan tersendiri dari anggota DPRD dalam proses legislasi itu sendiri.

Pembahasan dan pembuatan legislasi ini didasarkan pada beberapa faktor. Pertama, kelompok faktor kepentingan modal dan kekuasaan yang berpengaruh dalam memprioritaskan pembahasan undang-undang. Faktor ini merupakan kecenderungan yang ditemukan dalam anggota legislatif dalam pembuatan legislasi. Kedua, faktor penghambat performa DPRD yang buruk. Hal ini menjadi catatan tersendri bahwa performa kinerja DPRD yang buruk ditambah lagi banyaknya tuntutan dari kalangan anggota DPRD untuk memfasilitasi dirinya. Salah satu kabupaten yang memiliki kontribusi besar dalam PDB di Jawa Timur adalah Kabupaten Sidoarjo, dimana Kabupaten Sidoarjo merupakan satu dari tiga daerah kabupaten/kota dengan PDRB tertinggi dari 38 kabupaten/kota yang ada, selain Kota Surabaya dan Kota Kediri. Berdasarkan kemandirian keuangan daerah, Kabupaten Sidoarjo dilihat dari PAD maupun PDRB, menunjukkan kemampuan daerah dalam mengelola potensi dan sumber daya yang dimilikinya.

DPRD Kabupaten Sidoarjo lebih banyak melakukan pengawasan terhadap hasil dari perancangan APBD tersebut daripada harus membuat atau mengusulkan perancangan APBD yang baik dan berguna sesuai dengan kebutuhan. Hal ini yang menjadi kendala bagi setiap pengusulan rancangan perancangan APBD oleh DPRD. Namun, dari beberapa Peraturan Daerah (Perda) yang telah digodok di DPRD, hanya beberapa Perda yang berhasil disahkan oleh anggota DPRD tersebut. Terhitung sejak tahun 2016 sampai 2017 saja, anggota DPRD masih mempunyai tunggakan beberapa Perda yang belum diselesaikan. Hal ini terbukti bahwa kinerja anggota DPRD terkesan lamban dalam mengesahkan beberapa Perda penting. Pada tahun 2017, anggota DPRD mampu menyelesaikan 4 Perda, diantara lain Perda HIV/AIDS, Perda pencabutan pulau-pulau kecil, Perda APBD, dan Perda hak keuangan DPRD.

Upaya meningkatkan sistem pengaturan anggaran diperlukan perancangan undang-undang daerah salah satunya adalah Perubahan APBD tahun 2017 tentang Perubahan Anggaran Pendapatan dan Belanja Tahun Anggaran 2014 dimana dalam proses legislasi perubahan APBD tahun 2017. Dalam pembuatan Perubahan APBD tahun 2017 tentang Perubahan Anggaran Pendapatan dan Belanja Tahun Anggaran 2014 ada beberapa permasalahan yang sering terjadi dalam penyusunan Perda. Pertama, keterbatasan SDM, dana, dan sarana penunjang. Mayoritas perancangan APBD, baik di lingkungan 
Pemda maupun DPRD, tampaknya belum dapat menyesuaikan kemampuannya dengan tuntutan otonomi daerah yang mensyaratkan kapasitas yang memadai untuk menyusun peraturan. Pelatihan perancangan APBD yang diharapkan dapat meng-upgrade kemampuan perancang dan legislator masih jarang dilakukan. Dana juga tidak kalah penting dalam mendukung lancarnya proses penyusunan perancangan APBD. Selama ini, sebagian besar dana penyusunan perancangan APBD dialokasikan oleh pemerintah daerah. Seharusnya DPRD yang memiliki fungsi legislatif juga diberi anggaran yang cukup untuk menyusun peraturan. Kesulitan lainnya, sarana penunjang tidak memadai.

Permasalahan dalam penetapan anggaran Kabupaten Sidoarjo menjadi polemik di kalangan perbedaan kelompok kepentingan. APBD yang sudah disetujui oleh gubernur itu tiba-tiba berubah angka dari sebelumnya 4,18 T menjadi 4,26 T. Anggota badan anggaran baru mengetahui setelah APBD disahkan dan jumlahnya ternyata berbeda saat dibahas waktu rapat paripurna. Bangun mengatakan "telah terjadi penyimpangan dalam pengajuan APBD tahun 2017 oleh tim anggaran". Menurutnya, saat paripurna pada 30 November 2016 pengajuan anggaran untuk APBD 2017 senilai 4,18 T. Lalu, diserahkan kepada Gubernur Jawa Timur, Soekarwo. Berdasarkan sekian program yang diajukan Pemerintah Daerah Sidoarjo ada beberapa item yang dikoreksi oleh Soekarwo diantaranya pembangunan gedung terpadu dan pengadaan mobil dinas. Namun, evaluasi tersebut tidak merubah esensi ataupun angka di APBD. Hanya saja program yang dicoret diganti dengan program lain (Jatim.metrotvnews.com, n.d.). Item penambahan nilai yang dimasukkan tim anggaran antara lain, tunjangan profesi guru senilai Rp 79.510.442.332, pengadaan meja kursi guru senilai Rp. 165.375.000, serta pembelian gedung terpadu senilai lima milyar. Penambahan nilai APBD 2017 tidak melalui kesepakatan anggota DPRD sehingga terjadi penyimpangan dalam pengajuan APBD 2017 oleh tim anggaran. Adanya polemik dari perubahan angka APBD yang diajukan dari Rp 4,18 trilyun menjadi Rp 4,26 trilyun, sehingga pada saat pengesahan terjadi perbedaan jumlah APBD.

Pergantian pengambil kebijakan merupakan sebuah proses politik dalam perspektif historis. Kelompok kepentingan ini Gabriel A. Almond dan Bingham G. Powell. Proses politik secara historis merupakan sebuah upaya deskriptif-obyektif beberapa kejadian dan korelasinya dengan kejadian lainnya. Pendekatan yang integratif untuk menjelaskan unsur-unsur yang berinteraksi dan berproses (fungsional) dalam sistem politik. Adanya perubahan APBD khususnya karena keberagamannya kelompok kepentingan yang dibentuk mewakili kepentingan kelompok yang khusus atau spesifik, memiliki lembaga yang mapan, menggunakan tenaga profesional, memiliki prosedur yang teratur untuk merumuskan kepentingan dan tuntutan, kepemimpinan yang terseleksi dan tujuan yang bersifat khusus.

Terdapat beberapa peneliti yang memfokuskan penelitiannya pada perubahan anggaran terutama APBD. Perubahan Pendapatan Asli Daerah, perubahan Dana Bagi Hasil, dan perubahan Sisa Lebih Perhitungan Anggaran berpengaruh secara bersama-sama terhadap perubahan Belanja Bantuan Sosial pada pemerintah kabupaten/kota di Aceh (Amran, D., \& Abdullah, S., 2015). Perubahan anggaran tahun lalu dan besaran anggaran, baik secara simultan maupun parsial berpengaruh terhadap anggaran belanja langsung Satuan Kerja Pemerintah Kabupaten (SKPK) pada Kabupaten Aceh Besar (Meridiana, D., \& 
Abdullah, S., 2017). Perubahan anggaran pada masa menjelang Pemilu sering disalahgunakan oleh pejabat daerah untuk kepentingan kampanye dengan modus dana hibah atau dana bantuan. Ini terjadi karena adanya korupsi politik, yaitu eksploitasi politik oleh eksekutif dan legislatif daerah dalam upaya memperoleh keuntungan politik tertentu (Sulton, S., 2015). Dari beberapa penelitian di atas, melihat pengaruh perubahan anggaran terhadap kinerja pemerintah daerah. Namun, tidak ada yang melihat kontestasi politik dalam perubahan anggaran tersebut. Penelitian ini mencoba mengisi kekosongan tersebut dengan melihat kontestasi politik dalam perubahan anggaran yang terjadi di Kabupaten Sidoarjo.

\section{KERANGKA TEORI}

Elite menurut Suzzane Keller, berasal dari kata elligere, yang berarti memilih, dalam perkataan biasa, kata itu berarti bagian yang menjadi pilihan atau bunga suatu bangsa, budaya, kelompok usia, dan juga orang-orang yang menduduki posisi sosial yang tinggi. Dalam arti umum elite menunjuk pada sekelompok orang dalam masyarakat yang menempati kedudukan-kedudukan tertinggi. Dengan kata lain, elite adalah kelompok warga masyarakat yang memiliki kelebihan dari pada warga masyarakat lainnya sehingga menempati kekuasaan sosial di atas warga masyarakat lain (Keller, 1995).

Perbedaan yang tidak mungkin terelakkan diantara anggota masyarakat yang satu dengan yang lainnya dapat dinyatakan sebagai titik awal bagi munculnya kelompok-kelompok yang mempunyai keunggulan apabila dibandingkan dengan kelompok-kelompok yang lainnya dalam masyarakat yang sama. Anggota masyarakat yang mempunyai keunggulan tersebut pada gilirannya akan tergabung dalam suatu kelompok yang dikenal dengan sebutan kelompok elite. Keunggulan yang melekat pada dirinya akan menggiring mereka tergabung dalam kelompok elite yang mempunyai perbedaan dengan anggota masyarakat kebanyakan lainnya yang tidak memiliki keunggulan. Sebutan elite atau terminology elite, sebagaimana diungkapkan oleh Vilfredo Pareto, Gaetano Mosca, Suzanne Keller dan pemikir yang tergolong dalam elite theorits, memang menunjukkan pada kelompok atau golongan yang ada di suatu masyarakat. Suzanne Keller membagi elite menjadi dua golongan. Pertama, bahwa elite yang beranggapan golongan elite itu tunggal yang bisa disebut elite politik. Kedua, ahli yang beranggapan bahwa ada kelompok elite yang berbagi kekuasaan, tanggung jawab, dan hak-hak lainnya atau imbalan (Singkoh, 2012).

Elite itu merupakan suatu kelompok kecil yang mewakili tujuan sosial untuk melanjutkan tatanan sosial di masyarakat. Kelompok elite itu tumbuh dari adanya kelompok sosial yang organis dan terstruktur dimana dapat berhubungan langsung dengan masyarakat yang ada. Akan tetapi perlu adanya komunikasi dari dalam organ masyarakat iu sendiri.

Asumsi teori elite ini bahwasanya, kelompok masyarakat dibedakan menjadi dua. Pertama, kelompok yang memerintah atau elite yang berkuasa. Elite yang berkuasa dimana sekelompok kecil manusia memiliki kemampuan dan dapat memanfaatkan posisi penting tersebut. Kedua, kelompok yang diperintah. Kelompok elite yang berkuasa biasanya memonopoli kekuasaan dan memegang semua aspek 
dan fungsi politik itu sendiri. Golongan elite yang berkembang saat ini disebabkan oleh empat faktor yang utama, yaitu (1) pertumbuhan penduduk, (2) pertumbuhan spesialisasi jabatan, (3) pertumbuhan formal atau birokrasi, (4) perkembangan keragaman moral. Dengan adanya faktor tersebut, maka kelompok elite semakin mudah untuk bertumbuh banyak, semakin banyak, semakin beraneka ragam dan lebih otonom.

Selain terdapat elite yang menentukan penyususan anggaran daerah, terdapat kelompok kepentingan yang memengaruhi penyususan anggaran daerah. Definisi kelompok kepentingan di atas menjelaskan bahwa secara rasional kelompok kepentingan mencakup semua badan perantara yang menengahi posisi substansi negara dan masyarakat. Kelompok kepentingan dapat memainkan perannya memobilisasi kepentingan tertentu melalui Pemilu, memengaruhi proses perwakilan, menyediakan orang-orang dengan berbagai peluang untuk berpartisipasi, menyebarkan berbagai macam informasi, memberikan pengaruh pada pembuatan dan pelaksanaan kebijakan, dan berusaha untuk memiliki informasi atau opini yang menguntungkan yang tercermin dalam pengambilan keputusan.

Kelompok kepentingan (interest group) adalah setiap organisasi yang berusaha memengaruhi kebijakan pemerintah tanpa berkehendak memperoleh jabatan public, kecuali dalam keadaan luar biasa, kelompok kepentingan tidak berusaha menguasai pengelolaan pemerintahan secara langsung. Sekalipun mungkin pemimpin-pemimpin atau anggotanya memenangkan kedudukan-kedudukan politik berdasarkan pemilihan umum, kelompok kepentingan itu sendiri tidak dipandang sebagai organisasi yang menguasai pemerintahan (Wright, 2003).

\section{PEMBAHASAN}

Adanya paradigma dalam proses penyususan anggaran daerah yang disertai dengan pemaknaan politik anggaran. Pertanggungjawaban dalam penyusunan anggaran merupakan tuntutan bagi daerah sebagai pelaksana dan penyusurun rincian anggaran belanja daerah. Pada kenyataanya penyusunan anggaran tidak dapat dilepaskan dari aspek politik dan konflik anggaran yang merupakan uang rakyat yang diharapkan dapat memenuhi kebutuhan seluruh lapisan masyarakat. Namun, tidak dapat dipungkiri bahwa akuntabilitas anggaran telah memengaruhi proses penyusunan anggaran yang merupakan tuntutan penting dari pemerintah daerah. Politik anggaran adalah bagian yang integral dari upaya untuk menemukan suatu cara yang baik bagi pengelolaan anggaran agar bermanfaat secara sosial bagi rakyat.

Mekanisme anggaran telah dibuat melalui proses formal perundang-undangan. Namun, pada kenyataanya, masih terdapat adanya penyalahgunaan anggaran. Hal ini ditengarai akibat proses penyusunan anggaran masih didominasi oleh kepentingan kelompok atau kaum elite. Pada proses penyusuna anggaran ini, nilai-nilai keadilan dan menjunjung tinggi kebutuhan rakyat amatlah rendah pada saat praktik di lapangan. Apabila dilihat dari aspek politik, dapat disimpulkan bahwa keadaan ini merupakan dampak dari budgeting is political.

Proses penyusunan anggaran atau penganggaran awalnya merupakan cara pembuatan berbagai pilihan terhadap sesuatu dan pemilihan prioritas akan melakukan atau tidak melakukan sesuatu. 
Penyusunan anggaran diharapkan merupakan pilihan yang diambil dari langkah rasional, ekonomis, serta bebas dari kepentingan politik. Namun, diketahui bahwa dalam proses penyusunan sebuah anggaran belanja daerah, tentu akan tetap terdapat kepentingan politik yang hadir dikarenakan penyusun anggaran adalah para pelaku politik itu sendiri. Hal ini diperkuat dengan keadaan bahwa penganggaran menyangkut bargaining antara berbagai kekuatan untuk memilih prioritas dalam penyusunan anggaran. Sehingga dapat dilihat bagaimana politisasi dalam penganggaran dana terjadi.

Berdasarkan penggangaran dana, akan mempertemukan berbagai pendapat serta kebutuhan pada satu forum. Pada proses ini sekumpulan orang atau kelompok akan berkumpul untuk mengekspresikan kebutuhan dan keinginan yang berbeda, sehingga akan muncul ketetapan yang berbeda pula. Agar tujuan dari pihak tertentu itu tercapai, tentunya setiap pelaku dalam forum tersebut akan memberikan argumen tentang mana yang benar dan adil. Sementara pada pemerintah pun mengalami polemik karena setiap langkah dalam penentuan prioritas akan mengahasilkan kebijakan yang berbeda.

Dana yang dimiliki oleh negara dapat dikatakan terbatas, sehingga perlu adanya pemilihan prioritas dalam penyusunan anggaran. Anggaran pun tentu harus dibagi secara profesional agar dapat terpenuhi tujuan awal dari penganggaran dana ini. Maka, perlu adanya sistem mekanisme dalam membagi pilihan dalam penganggaran, yang mana sering terjadi konflik dalam perebutam kekuasaan atas dana tersebut. Bila suatu golongan berusaha untuk mendapatkan lebih banyak kekuasaan pada suatu proyek pembangunan dalam anggaran, dapat dipastikan bahwa stategi yang dilakukan adalah bagaimana mengatur dan memegang kendali atas anggaran tersebut.

Pada akhirnya akan terjadi kesenjangan pada kelompok-kelompok yang terlibat pada proses penganggaran tersebut. Sehingga kelompok yang lebih berkuasa dan memiliki kepentingan akan mendapat lebih banyak bagian dari pada kelompok lain. Anggaran memiliki beberapa tujuan yang sama beragamnya dengan tujuan para kelompok yang terlibat pada penyusunan anggaran dana daerah. Tujuan anggaran pada dasarnya adalah untuk mengkoordinasi berbagai aktivitas yang berbeda, saling melengkapi satu sama lain, namun juga untuk kesenangan beberapa pihak. Bisa dapat dilihat, apabila anggaran untuk suatu fasilitas yang dipergunakan untuk mereka, dengan cara memobilisasi kelompok lainnya. Seperti dibuat berbagai keputusan penting siapa yang menang, siapa yang kalah, siapa yang bakal mendapatkan bagian lebih besar dan siapa tidak dapat, karena proses kebijakan implisit atau eksplisit, sesungguhnya merupakan political choice.

Mengatasi permasalahan anggaran yang dipolitisasi, maka perlu adanya transparansi dan demokrasi yang harus diperbaiki pada sistem penganggaran dana. Persoalan anggaran dan demokrasi adalah sebuah paradigma baru dalam zaman modern ini, jika kaum elit yang memegang kekuasaan dapat memahami dan mengerti kebutuhan rakyat akan menampakkan wujud dan mencapai tujuan yang diinginkan. Demokrasi ini bertujuan untuk mengontrol pengaruh dan membangun tindakan pemerintah yang peduli terhadap negara dan rakyatnya. Demokrasi menjadi bagian output yang dihasilkan dari sebuah keputusan yang menjadi kebijakan selanjutnya. 
Demokrasi anggaran diperlukan untuk menjadi penyusunan anggaran yang mendukung pada kepentingan masyarakat umum, bukannya hanya pada golongan elite pemegang kekuasaan. Menurut Wildavsky \& Caiden (2004), dengan hal ini tiga demokrasi terhadap anggaran. Pertama, anggaran adalah persoalan rumit dan rewel. Untuk memahaminya seseorang harus memiliki kecakapan dan tingkat pendidikan tertentu, karena anggaran memiliki struktur, sistem, dan mekanisme. Kedua, anggaran hanyalah urusan-urusan proyek pembangunan dan sumber finansial lainnya. Ketiga, anggaran adalah semata-mata urusan yang boleh dimonopoli pemerintah hingga saat ini. Pemerintah mendudukkan anggaran sebagai persoalan yang sangat eksklusif, tanpa ada ruang keterlibatan bagi masyarakat.

Proses perumusan anggaran belanja daerah melibatkan banyak pihak dalam pelaksanaannya. Mulai dari bupati, politisi, hingga LSM, dan masyarakat yang menjadikan proses perumusan ini adalah bagian dari kegiatan berpolitik. Namun, setiap pihak yang terlibat memiliki perbedaan tujuan dan kepentingan yang akan menyebabkan terjadi konflik di dalam proses ini. Munculnya konflik untuk menjadikan pilihan tertentu sebagai prioritas utama dan lainnya menjadi disepelekan. Politisasi terhadap anggaran dana pun terjadi sebagai bagian dari usaha untuk mengambil kepentingan lebih besar dan keuntungan material lebih banyak. Dengan begitu, tujuan awal dari penganggaran ini tidak berjalan lancar dan terjadi penyelewengan. Dapat dilihat bagaimana uang yang berasal dari pemerintah pusat digunakan untuk kepentingan pribadi oleh daerah.

Kecenderungan daerah yang bergantung dari APBN membuat beban negara menjadi lebih berat karena daerah belum bisa mandiri untuk memenuhi kebutuhan pembangunan di daerahnya sendiri. Padahal, dengan adanya aturan desentralisasi ini diharapkan daerah dapat mandiri dalam mengembangkan potensi daerahnya masing-masing. Sehingga pemenuhan APBD dapat bersumber dari pendapatan daerah itu sendiri tanpa bergantung pada dana gelontoran dari APBN.

Namun, dengan adanya politisasi dan hak daerah untuk mengatur pengeluaran dan pengajuan dari negara, membuat adanya penyelewengan kekuasaan. Upaya untuk menggunakan kekuasaan tertentu untuk mengatur dan memonopoli pengganggaran dana sebagai bagian untuk memenuhi kebutuhan golongan. Maka dari itu dibutuhkan demokrasi anggaran sebagai solusi agar dana dari negara ini dapat dipertanggungjawabkan secara maksimal oleh pihak-pihak yang terlibat pada proses pengganggaran ini.

Kecenderungan daerah yang bergantung dari APBN membuat beban negara menjadi lebih berat karena daerah belum bisa mandiri untuk memenuhi kebutuhan pembangunan di daerahnya sendiri. Padahal, dengan adanya aturan desentralisasi ini diharapkan daerah dapat mandiri dalam mengembangkan potensi daerahnya masing-masing. Sehingga pemenuhan APBD dapat bersumber dari pendapatan daerah itu sendiri tanpa bergantung pada dana gelontoran dari APBN. Namun, dengan adanya politisasi dan hak daerah untuk mengatur pengeluaran dan pengajuan dari negara, membuat adanya penyelewengan kekuasaan. Upaya untuk menggunakan kekuasaan tertentu untuk mengatur dan memonopoli pengganggaran dana sebagai bagian untuk memenuhi kebutuhan golongan. Maka dari itu 
dibutuhkan demokrasi anggaran sebagai solusi agar dana dari negara ini dapat dipertanggungjawabkan secara maksimal oleh pihak-pihak yang terlibat pada proses pengganggaran ini.

Kontestasi elite politik telah terjadi di Kabupaten Sidoarjo meskipun memiliki interaksi yang saling berkoordinasi antara kelompok kepentingan dalam penyusunan Perda tentang perubahan APBD. Penyusunan APBD diawali dari Rencana Kerja Pemerintah Daerah (RKPD) yang sesuai dengan visi misi walikota, antara RKPD dengan KUA (Perubahan APBD Tahun 2017) dan PPAS (Prioritas Plafon Anggaran Sementara), sehingga APBD merupakan wujud keterpaduan seluruh program daerah yang merupakan anggaran prioritas.

Penyusunan perubahan APBD Tahun 2017 (KUA) merupakan tahapan perencanaan pembangunan untuk menghasilkan dokumen yang berisi kebijakan bidang pendapatan, belanja, dan pembiayaan serta asumsi yang mendasarinya untuk periode 1 (satu) tahun sebagai perincian lebih teknis dari Rencana Kerja Pembangunan Daerah (RKPD). Kebijakan pembangunan tahunan yang didukung oleh penganggaran dituangkan dalam Perubahan APBD Tahun 2017 (KUA), yang merupakan implementasi dari RKPD, dengan sumber penganggaran dari dana APBD sebagai acuan dalam penyusunan Plafon dan Prioritas Anggaran Sementara (PPAS) dan Rancangan Anggaran Pendapatan dan Belanja Daerah (rancangan perubahan APBD Tahun 2017).

Perubahan APBD Tahun 2017 Kabupaten Sidoarjo Tahun Anggaran 2014 memuat programprogram yang akan dilaksanakan oleh pemerintah daerah untuk setiap urusan pemerintahan daerah yang disertai dengan proyeksi perencanaan pendapatan daerah, alokasi belanja daerah, sumber dan penggunaan pembiayaan yang disertai dengan asumsi yang mendasarinya. Penetapan prioritas pembangunan tahun 2017 didasarkan atas pertimbangan, (1) memiliki dampak yang besar terhadap pencapaian sasaran sehingga langsung dapat dirasakan manfaatnya oleh masyarakat, (2) mendesak dan penting untuk segera dilaksanakan, (3) merupakan tugas pemerintah sebagai pelaku utama, dan (4) realistis untuk dilaksanakan.

Rancangan Perubahan APBD Tahun 2017 yang juga merupakan kebijakan politik pemerintah daerah dirumuskan dengan maksud agar proses penyusunan rancangan perubahan APBD Tahun 2017 dapat dilaksanakan secara efektif dan efisien, serta mampu secara komprehensif mengakomodir dinamika politik pembangunan Pemerintah Pusat dan Daerah sehingga dapat mempertahankan pencapaian tujuan pembangunan pemerintah pusat dan daerah, sekaligus menjadi indikator kinerja yang akan digunakan dalam menilai efektivitas pelaksanaannya selama kurun waktu satu tahun kedepan. Selama penelitian berlangsung, terdapat fakta bahwa sebagian besar anggaran legislatif digunakan untuk keperluan birokrasi. Dalam hal ini dibahas dalam rapat penyusunan dan pembahasan rancangan perubahan APBD Tahun 2017.

Penyusunan rancangan perubahan APBD Tahun 2017 berasal dari KUA dan PPAS, pemerintah daerah bersama dinas-dinas terkait membuat rencana kerja pemerintah daerah. Kemudian DPRD membahas KUA, setelah mendapatkan kesepakatan antara DPRD dan bupati dengan hasil nota kesepakatan dan penyampaian PPAS. Kemudian, DPRD dan bupati mengadakan pembahasan. Jumlah 
produk hukum yang dihasilkan selama tahun anggaran 2009-2017 di Kabupaten Sidoarjo. Daftar Peraturan Daerah yang disahkan. Berdasarkan daftar di atas, dapat diketahui bahwa banyak hasil peraturan daerah yang lebih mementingkan eksekutif, misalnya jenis peraturan tentang organisasi dan tata kerja eksekutif. Selain itu, peraturan yang dibuat hanya untuk masyarakat yang justru membebani, misalnya peraturan daerah tentang pajak dan retribusi.

Ada beberapa hal yang harus diingat bahwa dinamika politik lembaga kelompok kepentingan dalam Perubahan APBD Tahun 2017, memiliki fungsinya masing-masing tidak sepenuhnya berada ditangan walikota ataupun DPRD. Secara proposional, kewenangan legislatif mengajukan rancangan peraturan daerah sebagai hak bukan kewajiban. Sehingga lembaga legislatif harus lebih aktif dalam menyaring aspirasi masyarakat, agar program dan kegiatan yang dibuat oleh pemerintah memang tepat untuk rakyat, bukan sebagai money politic. Penyelenggaraan pemerintahan daerah oleh pemerintah daerah dan DPRD menurut asas desentralisasi pemerintahan daerah adalah penyelenggaraan urusan pemerintah oleh pemerintah daerah dan DPRD menurut asas otonomi dan tugas pembantu dengan prinsip otonomi seluas-luasnya dalam sistem dan prinsip Negara Kesatuan Republik Indonesia tahun 1945. Mekanisme tersebut telah berjalan sebagai interdependensi antara lembaga kelompok kepentingan pada proses penetapan rancangan perubahan APBD Tahun 2017. Interdependensi yang terjadi antara kelompok kepentingan adalah dalam hal merancang sebuah kebijakan. Kelompok kepentingan harus saling memberi inisiatif dalam merumuskan peraturan daerah, agar terwujudnya check and balances dalam pemerintahan. Namun, wacana ini tidak terealisasi dengan baik. Lembaga eksekutif masih tampak mendominasi dalam hal inisiatif dalam penyelenggaraan pemerintahan di Kabupaten Sidoarjo. Sebagian anggota DPRD Kabupaten Sidoarjo yang tidak mengetahui, mengerti, dan memahami subtansi yang terkandung dalam tata tertib DPRD, terutama yang mengatur tentang prosedur pelaksanaan hak inisiatif.

Hubungan politik antara kelompok kepentingan salah satunya adalah perumusan peraturan daerah, dimana lembaga kelompok kepentingan memiliki kesetaraan dalam membuat peraturan daerah. Dalam menjalankan hubungan politik, bukan hanya eksekutif yang dapat merancang peraturan daerah. Namun, legislatif juga memiliki hak inisiatif untuk merancang peraturan daerah. Dalam penyususan peraturan daerah harus memperhatikan urusan pemerintahan yang menjadi kewenangannya. Pembagian urusan pemerintahan terdapat pada Peraturan Pemerintah Nomor 38 Tahun 2008 tentang pembagian urusan pemerintahan antara pemerintah, pemerintah daerah provinsi dan pemerintah daerah kabupaten/kota, menegaskan bahwa urusan pemerintahan terdiri dari urusan wajib dan urusan pilihan. Struktur APBD terdiri dari pendapatan, belanja, dan pembiayaan belanja diklasifikasi dalam urusan pemerintahan (wajib dan pilihan, organisasi, program, kegiatan, jenis, obyek, dan rincian obyek belanja). Kelompok belanja dikategorikan belanja langsung dan belanja tidak langsung. Sedangkan pendapatan dikategorikan dalam pendapatan asli daerah, dana perimbangan, dan pendapatan daerah yang sah.

Penyusunan Perda tentang perubahan APBD merupakan kebijakan pemerintah daerah yang menjadi petunjuk dan ketentuan yang disepakati sebagai pedoman penyusunan rancangan APBD. 
Memiliki tahapan panjang dari penyusunan APBD, kemudian implementasi, dan yang terakhir evaluasi. Rancangan Peraturan Daerah berasal dari eksekutif, kondisi ini sangat memprihatinkan bagi perkembangan lembaga legislatif Daerah Kabupaten Sidoarjo.

Proses perubahan anggaran daerah didasarkan pada peraturan perundang-undangan yang terkait dengan sistem penganggaran daerah. Kegiatan penyusunan anggaran pada dasarnya merupakan rangkaian kegiatan dalam proses perencanaan daerah yang terbagi dalam tiga tahapan besar, yakni penyusunan kebijakan, program/kegiatan, dan penyusunan pembiayaan atau penganggaran yang bermuara pada rencana APBD (RAPBD) dan APBD. Adapun penganggaran daerah terdiri atas formulasi perubahan anggaran (terkait analisis fiskal) dan perencanaan operasional anggaran (alokasi sumber daya) (Munir, 2003: 85).

APBD sebagai dokumen rencana keuangan pemerintahan daerah mencerminkan pengambilan keputusan menyangkut perubahan anggaran. APBD merupakan kompilasi dari program dan kegiatan beserta pembiayaannya dari masing-masing SKPD. Proses penyusunan APBD tahunan di Kabupaten Sidoarjo dimulai dari penyusunan RKPD yang menjabarkan prioritas dan sasaran pembangunan tahunan beserta rencana program-program prioritas daerah. RKPD tersebut selanjutnya menjadi pedoman dalam penyusunan arah kebijakan umum anggaran (KUA), prioritas dan plafon anggaran sementara (PPAS), rencana kerja anggaran-satuan kerja perangkat daerah (RKA-SKPD) tahunan, dan RKA dari masingmasing SKPD tersebut dikompilasi menjadi RAPBD, yang selanjutnya menjadi APBD dalam bentuk peraturan daerah (Perda). Dengan demikian, penyusunan APBD merupakan sebuah proses yang melibatkan masyarakat di dalamnya. Karena itu, proses penyusunan APBD mencerminkan upaya pemerintah daerah bersama DPRD untuk mengakomodasi berbagai kepentingan dan kebutuhan masyarakat ke dalam kebijakan, program/kegiatan dan pengalokasiannya dalam APBD.

Aktor perumus perubahan anggaran meliputi unsur pemerintah daerah, yakni (1) Kepala Daerah beserta Tim Anggaran Pemerintah Daerah (TAPD), (2) Bappeda sebagai koordinator perencana pembangunan daerah, dan (3) SKPD (Dikpora) sebagai penyusun program-program pendidikan beserta pembiayaannya. Sementara, dari unsur DPRD, yaitu (1) unsur pimpinan dewan, (2) komisi, (3) fraksi, (4) Badan Anggaran (Banggar), dan (5) anggota DPRD.

Proses penyusunan perubahan anggaran daerah/APBD, komitmen pemerintah daerah menjadi prasyarat penting dalam menghasilkan perubahan anggaran yang berorientasi pada kepentingan publik. Komitmen pemerintah daerah terhadap kepentingan masyarakat dalam proses penyusunan APBD Kabupaten Sidoarjo, tercermin salah satunya melalui penerapan kebijakan alokasi Pagu Indikatif Usulan Kecamatan (PIK) dari APBD sejak tahun 2016 untuk perencanaan pembangunan tahun 2017. PIK ini merupakan strategi perencanaan partisipatif agar kebijakan pembangunan dapat dinikmati oleh masyarakat secara adil dan merata. Dengan demikian, kebijakan alokasi PIK tersebut mencerminkan niat dan upaya pemerintah daerah terhadap visi dan misi maupun prioritas pembangunan daerah. Praktisnya, PIK bertujuan agar aspirasi dan kebutuhan masyarakat berupa program-program prioritas pembangunan (fisik maupun non-fisik) yang diputuskan melalui musyawarah perencanaan 
pembangunan (Musrenbang) desa, yang difinalisasi pada Musrenbang kecamatan dan diselaraskan pada Musrenbang tingkat kabupaten, akan lebih diakomodir dalam APBD.

Namun demikian, program-program pembangunan yang dihasilkan melalui Musrenbang tidak jarang belum mencerminkan aspirasi dan kebutuhan masyarakat. Belum adanya publikasi yang memadai terhadap usulan kebutuhan masyarakat yang direspon atau tidak diakomodir oleh pemerintah daerah menyebabkan minimnya informasi bagi masyarakat, khususnya tentang penggunaan dana APBD. Di sektor pendidikan misalnya, usulan program-program prioritas masyarakat melalui PIK 2016 telah diakomodir dalam APBD 2017, seperti salah satunya program pembangunan dan rehabilitasi gedung Pendidikan Anak Usia Dini (PAUD).

Akhir November tahun lalu, Pemkab dan DPRD Sidoarjo bersepakat menetapkan kekuatan Anggaran Pendapatan dan Belanja Daerah (APBD) 2017, mencapai Rp 4,18 triliun. Namun, dalam perkembangannya, besaran itu ternyata berubah. Ada tambahan $\mathrm{Rp} 84,75$ miliar sehingga kekuatan APBD 2017 mencapai Rp 4,26 triliun. Tambahan anggaran yang tiba-tiba muncul tersebut mengagetkan di kalangan internal anggota DPRD. Perubahan penambahan anggaran APBD 2017. Timgar merevisi besaran total APBD. Nilainya bertambah Rp 84,75 miliar, seperti dana alokasi khusus (DAK) sebesar Rp 639 juta, bantuan keuangan (BK) Provinsi Jalin Matra senilai Rp 75 juta, dan tunjangan profesi guru (TPG) sebesar Rp 79,5 miliar. Selain itu, terdapat perubahan dari pengadaan tanah untuk gedung terpadu Rp 5 miliar.

Perubahan APBD Kabupaten Sidoarjo tahun 2017 tersebut dilakukan oleh pihak eksekutif, memang menjabarkan perincian adanya penambahan kekuatan APBD itu. Namun, perubahan tersebut tentu menimbulkan reaksi dari kalangan wakil rakyat. Perubahan anggaran tersebut diperuntukkan guru dan dana pembangunan dari Pemerintah Provinsi Jawa Timur. Hasil wawancara dengan Bapak Yudi menjelaskan bahwa penambahan anggaran dalam APBD masih diperbolehkan. Landasan hukumnya terdapat dalam Peraturan Menteri Dalam Negeri (Permendagri) Nomor 31 Tahun 2016 tentang Pedoman Penyusunan APBD Tahun Anggaran 2017. Sesuai ketentuan tersebut, dana bantuan bisa langsung masuk APBD. Penambahan anggaran itu memang diperbolehkan. Misalnya, APBD Sidoarjo diketok, sedangkan APBD Pemprov belum. Perbedaan kelompok kepentingan seharusnya penambahan nominal harus disampaikan lebih dulu kepada pimpinan DPRD sehingga terdapat dalam perubahan anggaran keuangan (PAK).

Kelompok kepentingan dalam masyarakat modern seringkali melakukan agregasi kepentingan atau mengubah tuntutan-tuntutan menjadi alternatif kebijakan. Namun, regulasi kelompok kepentingan lebih bebas dibandingkan partai politik, karena tidak berjuang mencari kursi parlemen. Kelompok kepentingan (interest groups) mengandung arti sejumlah orang yang memiliki kesamaan sifat, sikap, kepercayaan dan tujuan yang sepakat mengorganisasikan diri untuk melindungi dan mencapai tujuan. Kelompok kepentingan juga diartikan organisasi yang berusaha memengaruhi suatu kebijakan seperti yang penulis coba bahasa dalam hasil penelitian. 


\section{KESIMPULAN}

Kontestasi elite politik dalam proses legislasi perubahan APBD Tahun 2017 dijelaskan dengan adanya kontestasi pihak elite politik seperti kelompok kepentingan mengembangkan potensinya dan meningkatkan kapasitasnya secara bersama-sama sehingga memiliki pemahaman yang sama baiknya dalam menyikapi setiap isu perubahan APBD Tahun 2017 dan implementasinya. Pihak yang berkontestasi adalah pihak eksekutif dari tim anggaran Kabupaten Sidoarjo dan pihak wakil rayat DPRD Kabupaten Sidoarjo dalam arena perubahan APBD Kabupaten Sidoarjo Tahun 2017 tentang anggaran Dinas Pendidikan Kabupaten Sidoarjo. Dinas Pendidikan yang mengajukan perubahan anggaran tidak mendapatkan persetujuan dari DPRD Kabupaten Sidoarjo. Konstestasi elite politik telah berkembang di Kabupaten Sidoarjo, dimana fungsi anggaran dimiliki lembaga legislatif yang dijadikan alat tawar menawar terhadap eksekutif dalam memenuhi kebutuhan legislatif. Hubungan secara negatif terjadi bila kelompok kepentingan berkoalisi (KKN) dalam penyelenggaraan pemerintahan dan secara bersama-sama menyembunyikan kalaborasi tersebut kepada publik, baik dalam penganggaran maupun dalam perumusan perubahan APBD. Pada proses pembahasan peraturan daerah di legislatif, muncul perbedaan pendapat antar anggota DPRD meskipun perbedaan itu tidak terlalu kuat. Dalam pembahasan di DPRD, kontestasi politik pembuatan Perda didominasi oleh perbedaan kepentingan eksekutif dan legislatif. Hal yang diperjuangkan dalam konstelasi politik terhadap perubahan APBD Tahun 2017 dijelaskan kepentingan antara badan legislatif dan eksekutif terutama dinas pendidikan yang membela kepentingan guru dan kebutuhan pendidikan. Hal yang diperjuangkan oleh lembaga eksekutif dengan tinjauan alokasi, anggaran belanja APBD tahun 2017 cenderung berpihak pada belanja (kepentingan) birokrasi dari pada pemanfaatannya untuk kepentingan publik. Cara memperjuangkannya dengan cara melakukan pembahasan APBD Perubahan (APBDP) tahun 2017 dibingkai dalam perdebatan argumentatif terkait pemanfaatan dana SiLPA 2016 pada APBDP 2017 untuk Pemberian Pinjaman Daerah (PPD) ke bank daerah. Di tingkat panitia khusus (Pansus) DPRD, proses pembahasan penyertaan modal (PPD) tersebut diwarnai dengan tarik-ulur kepentingan, sehingga realisasinya hanya sekitar 40 milyar dari kesepakatan semula, yakni sekitar 92,5 milyar dalam APBDP.

\section{DAFTAR PUSTAKA}

Amran D \& Abdullah S (2015) Pengaruh Perubahan Pendapatan Asli Daerah, Perubahan Dana Bagi Hasil, dan Perubahan Sisa Lebih Perhitungan Anggaran Terhadap Perubahan Belanja Bantuan Sosial (Studi pada Pemerintah Kabupaten/Kota di Aceh). Jurnal Administrasi Akuntansi: Program Pascasarjana Unsyiah, 4(1).

Bourdieu P (1979) La Distinction Critique Sociale Du Jugement. Paris: Minuihlm.

Farizal (2007) Kontestasi Wacana Partai Politik di Tingkat Lokal pada Pemilihan Kepala Daerah di Media Cetak (Critical Discourse Analysis terhadap Pemberitaan Pemilihan Kepala Daerah di Kabupaten Sleman pada Tahun 2005 pada Harian Kedaulatan Rakyat, Radar Jogja, dan Kompas Edisi Yogyakarta. Yogyakarta: Sekolah Pascasarjana UGM.

Keller S (1982) Pengauasa dan Kelompok Elit: Peranan Elit Penentu dalam Penentu Masyarakat Modern. Jakarta: CV Rajawali. 
Meridiana D \& Abdullah S (2017) Pengaruh Sisa Anggaran Sebelumnya, Perubahan Anggaran Tahun Lalu dan Besaran Anggaran Terhadap Anggaran Belanja Langsung Satuan Kerja Perangkat Kabupaten (SKPK) pada Kabupaten Aceh Besar. Jurnal Administrasi Akuntansi: Program Pascasarjana Unsyiah, 6(2).

Rubin EL (1991) Legislative Methodology: Some Lessons from the Truthin Lending Act, 80 GEO.L/233.

Sukirno D (2011) Membela Desa dengan Desentralisasi dan Melawan Desa dengan Demokrasi. Jurnal Yustika, 12(2).

Sulton S (2015) Siklus Politik Anggaran di Kabupaten Ponorogo: Studi Kasus Dana Hibah dan Bantuan Sosial APBD 2013. Jurnal ARISTO, 5. 